\title{
Progress of Engineering Seismology in Japan, Specially Related with Strong Motion Prediction
}

\author{
-An Introduction to the Series of Reviews on Strong Motion \\ Seismology and Engineering Seismology-
}

\author{
Kazuyoshi Kudo \\ Earthquake Research Institute, the University of Tokyo \\ 1-1-1, Yayoi, Bunkyo-ku, Tokyo 113, Japan \\ (Received July 10, 1993; Accepted August 3, 1993)
}

\begin{abstract}
A series of review articles on engineering seismology will be published in this and following volumes. This is a brief review to outline a 40 -year progress of studies in the field of engineering seismology in Japan.

The first stage of engineering seismology in Japan is represented by the development and installation of SMAC-type strong motion accelerograph, Kawasumi's map and Kanai's empirical formula for estimating strong ground motion.

During a decade of 1960 , some significant strong motion records were obtained and an idea on site amplification of earthquake ground motion due to S-wave multiple-reflection came to a common understanding with a help of S-wave velocity measurement in the soft ground.

The topics of a decade of 1970 are that a dislocation source model was brought in the field of engineering seismology and the period range of earthquake ground motion in the field of engineering seismology was extend from $1 \mathrm{~s}$ to longer period than $10 \mathrm{~s}$.

Predictions of earthquake ground motion taking into a complex rupture process and irregular ground structures came to a major target since 1980 .
\end{abstract}

Key words: Strong motion seismology, Engineering seismology, Strong ground motion prediction.

\section{§1.はじめに}

本号以降, いわゆる地震工学関連の総合報告がシリー ズで掲載される機会を得た. 1967 年に, 地震特集号「日 本の地震学の概観」が刊行され, その第 5 編で地震工学 の総合報告がまとめられているが，それから現在に至る まで, 地震学会としてのまとまった形での地震工学関係 の総合報告はない，今回の地震工学に関する総合報告の 企画・編集は入倉孝次郎 (京都大学防災研究所), 笹谷 努 (北海道大学理学部), 緬維一起 (東京大学地票研究 所), 工藤一䕒 (東京大学地票研究所) で行ったが, 近年

\footnotetext{
* ₹113 東京都文京区弥生 1-1-1
}

急速に進展している強震動地震学 (Strong motion seismology) と地震学の応用研究としての地震工学 (Engineering Seismology) の現状と展望を紹介してもらうよ う各執筆者に依頼している.

一口に地震工学と言えば, Earthquake Engineering の訳を意味し [金井 (1969)], 地震学, 建築工学, 土木工 学, 機械工学, 土質工学などを基礎として地震災害軽減 の目的を持つ研究を広く包含している. 近年では社会 学, 経済学などを基礎とした研究へも広がりを持ち、「地 震」を鍵として多くの学際領域を含んでいる. 本シリー ズは, この Earthquake Engineering 全体の総合報告を 意図してはいない. Strong Motion Seismology および 
Table. Progress of research subjects in the field of engineering seismology in Japan.

\begin{tabular}{|c|c|c|c|c|}
\hline \multirow{2}{*}{ 項 } & \multicolumn{4}{|c|}{ 年 } \\
\hline & 1950 年代 & 1960 年代 & 1970 年代 & 1980 年代 \\
\hline 地震動観測 & $\begin{array}{l}\text { 日本の強震観測開始 } \\
\text { (SMAC 型強震計の開 } \\
\text { 発) } \\
\text { 地下の地震観测 }\end{array}$ & $\begin{array}{l}\text { SMAC 型強震計の全 } \\
\text { 国配備 } \\
\text { 地中地震計・地中観測 }\end{array}$ & $\begin{array}{l}\text { 強震アレイ観測の提唱 } \\
\text { (ディジタル強震計の } \\
\text { 開発) } \\
\text { 気象庁 } 1 \text { 倍強震計記 } \\
\text { 録の利用 }\end{array}$ & $\begin{array}{l}\text { 強震アレイ観測の実施 } \\
\text { （強震記録のテレメー } \\
\text { 夕化） } \\
\text { 気象庁 } 87 \text { 型強震計の } \\
\text { 全国配備 }\end{array}$ \\
\hline 顕著な地震 & （福井地震, 1948） & $\begin{array}{l}\text { 広尾・新潟・松代地震 } \\
\text { 十勝沖, Parkfield 地 } \\
\text { 震 }\end{array}$ & $\begin{array}{l}\text { 伊豆半島沖, 宮城県沖 } \\
\text { 地震等 } \\
\text { San Fernando 地震 } \\
\text { Imperial Valley 地震 }\end{array}$ & $\begin{array}{l}\text { 日本海中部地震 } \\
\text { Michoacan (Mexico) } \\
\text { 地震 } \\
\text { Loma Prieta 地震 }\end{array}$ \\
\hline 地震動予測 & 金井式 & $\begin{array}{l}\text { 金井式・震源近傍への } \\
\text { 適用 }\end{array}$ & $\begin{array}{l}\text { 強震記録を用いた距離 } \\
\text { 減衰式 } \\
\text { 特定地震による地震動 } \\
\text { 予測 } \\
\text { 長周期強震動予測 }\end{array}$ & $\begin{array}{l}\text { 経験式の精密化, 震源 } \\
\text { 近傍への適用 } \\
\text { 経済的グリーン関数法 } \\
\text { による地震動予测 }\end{array}$ \\
\hline 震源 & マグニチュード & $\begin{array}{l}\text { 断層モデル十 } \\
\text { シミュレーション（無 } \\
\text { 限） } \\
\text { スケーリング則 }\end{array}$ & 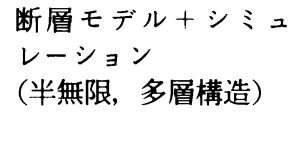 & $\begin{array}{l}\text { 断層の不均質運動の解 } \\
\text { 明 } \\
\text { （震源インバージョン） }\end{array}$ \\
\hline 地盤探查 & $\mathrm{P}$ 波,（表面波） & $\begin{array}{l}\mathrm{S} \text { 波（実測） } \\
\text { : 板叨き法 } \\
\text { : 孔中地震計 }\end{array}$ & $\begin{array}{l}\text { 都市域中規模人工地震 } \\
\text { 探查 } \\
\mathrm{S} \text { 波速度と土質の対比 } \\
\text { 深層ボーリング・探查 }\end{array}$ & $\begin{array}{l}\text { 都市域人工地震探査 } \\
\text { (屆折・反射) } \\
\text { (関東・濃尾・大阪平 } \\
\text { 野等) } \\
\text { (3 次元地下構造) }\end{array}$ \\
\hline （対象深さ） & 数 $10 \mathrm{~m}$ & $100 \mathrm{~m}$ 以下 & 数百 $\mathrm{m}$ ～数 $\mathrm{km}$ & 数百 $\mathrm{m}$ 数 $\mathrm{km}$ \\
\hline 対象波動・周期 & $\mathrm{S}$ 波（提唱） & $\begin{array}{l}\mathrm{S} \text { 波の多重反射, } 1 \text { 秒 } \\
\text { 以下 } \\
\left(\text { 地震基盤 1: } V_{\mathrm{S}} \sim 700\right. \\
\mathrm{m} / \mathrm{s})\end{array}$ & $\begin{array}{l}\text { 堆積層表面波, } 2 \cdot 3 \\
\text { 秒以上 } \\
\text { (地震基盤 } 2: V_{\mathrm{s}} \sim 3 \\
\mathrm{~km} / \mathrm{s} \text { ) }\end{array}$ & $\begin{array}{l}\text { 不規則構造での波動伝 } \\
\text { 播 } \\
\text { (数値シミュレーショ } \\
\text { ンの発展) }\end{array}$ \\
\hline 微動 & 常時微動測定 & $\begin{array}{l}\text { 地盤種別評価への提案 } \\
\text { 微動の本性に関する検 } \\
\text { 討 }\end{array}$ & $\begin{array}{l}\text { やや長周期（1～5 秒） } \\
\text { 微動 }\end{array}$ & $\begin{array}{l}\text { アレイ観測による地下 } \\
\text { 構造の決定 }\end{array}$ \\
\hline 構造物 & 低・中層 & $\begin{array}{l}\text { 高層化, 超高層ビルの } \\
\text { 出現 } \\
\text { 原子力発電所 }\end{array}$ & $\begin{array}{l}\text { 超高層ビルの普及, 長 } \\
\text { 大橋 } \\
\text { 大型化, 線状構造物 }\end{array}$ & 免震 - 制震構造物 \\
\hline 地域地震危険度 & $\begin{array}{l}\text { マクロゾーネイション } \\
\text { (河角マップ) }\end{array}$ & 震度の通信・面談調查 & $\begin{array}{l}\text { マイクロゾーネイショ } \\
\text { ン } \\
\text { 震度のアンケート調査 }\end{array}$ & $\begin{array}{l}\text { 高密度震度分布, 避 } \\
\text { 難・人間行動 } \\
\text { 活断層を考慮した地震 } \\
\text { 危険度 }\end{array}$ \\
\hline その他特記事項 & $\begin{array}{l}\text { 建築基準法 } \\
\text { 各種土木施設耐震基準 } \\
\text { World Conf. Earthq. } \\
\text { Engineering }\end{array}$ & $\begin{array}{l}\text { 新潟地震：地盤の液状 } \\
\text { 化 } \\
\text { 広尾沖地震：釧路大加 } \\
\text { 速度 } \\
\text { 十勝沖地震: 鉄筋コン } \\
\text { クリート造の大被害 } \\
\text { 地震予知研究計画 }\end{array}$ & $\begin{array}{l}1 \mathrm{~g} \text { 強の観測記録 } \\
\text { 大規模地震対策特別措 } \\
\text { 置法 } \\
\text { (仮想東海 (僁河湾) 地 } \\
\text { 震) } \\
\text { プレートテクトニクス }\end{array}$ & $\begin{array}{l}\text { 建築基準法施工令改正 } \\
\text { 国際防災の } 10 \text { 年（提 } \\
\text { 唱） } \\
\text { 「表層地質の地震動へ } \\
\text { の影響」ワーキンググ } \\
\text { ループ }\end{array}$ \\
\hline
\end{tabular}

Engineering Seismology に分類される主として地震学 からの工学への応用研究の成果に限定した総合報告を企 画している. Engineering Seismology は「工学地震学」 と訳されたりあるいは「応用地票学」としてその意を伝 えようとされているが, 必ずしあ広く受け入れられてい

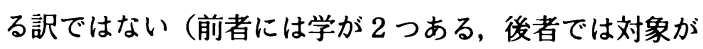
不明確等の批判がある).これからシリーズで紹介され る各総合報告は, 地震学の知識之直接的に関連する内容 を基調としている.上に述べたように Engineering Seismology は地震工学全体を意味しないが, 地震学会 
で暗默的に使われている「地震工学」に相当しており, 本論では特に断らない限り, 便宜的に「地震工学」を使 うこととしたい.

本論はこのシリーズの序章として位置づけ, 地震工学 関連の研究成果を概観する. 本論に続く総合報告は, 各 テーマ毎にしかも最先端の研究を紹介する内容になって いる. そのため, 本論では工学と地震学の接点である強 震動予測・評価の問題を中心として，1970・1980 年代 を重点的に, 若干それ以前の研究を含める形でやや横断 的に研究のあゆみを概観したい。

\section{§2. 研究のテーマ・成果の経緯}

地震学から地震工学へのアプローチで最も重要な課題 の一つは, 来るべき大地震による強震動を的確に予測す ることにあり，そのためには震源での断首運動の時空間 特性, 伝播経路での地震動の減哀・散乱や時には增幅な ど, さらには観測点や予測対象地点（地域）の表首地質 （地形・地盤構造）による影響などを定量的に評価しな ければならない. Table は強震動観測・被害等と地震動 予測を中心としたわが国での地震工学の発展とテーマの 変遷を概観したものである. 項目 (研究テーマ, 分野) の 選び方や内容に異論のむきも多々あると考えるが, Tableに沿って研究の流れを追ってみたい，また，10年 毎に一応区切ってあるが, 各年代にわたる事項ああり, おおよその目安と考えて戴きたい.

研究の発展に直接影響を与えたものは, 地震被害の内 容，そこで得られた強震記録や被害・震度調査記録を筆 頭にあげることができよう，さらに地震学固有の研究成 果や物理探查技術の発展に刺激され，また新しい構造物 の出現によって対象波動・周期等が変化してきた。

\section{1 地震工学のあけぼの期（1950 年代）}

1950 年代は, わが国の地震工学研究のあけぼの期と 言える. 1948 年の福井地震が契機となってわが国独自 の SMAC 型強震計が試作され [高橋 (1953)], 地震工学 における計測的研究のさきがけとなった．ほぼ時期を同 じくして気象庁の変位型強震計（通称 1 倍強震計）の開 発之全国気象官署への配備が行われたが，当時この記録 の利用はほぼ地震学関係者に限られ, 地震工学への利用 は 1970 年代に入ってからになる。一方, SMAC 型強震 計は構造物を中心に設置されたことや時刻が不明である ことに起因していると考えられるが, 観測記録が地震学 者の興味を引くようになったのは，これも 1970 年代に 入ってからと言えよう.

地震の発生予測・活動度の把握は当時から現在に至る まで地震学固有の研究対象であるが, 地震工学の分野に おいても地震対策や耐震設計の基礎である地震動入力を
策定する上での根幹となっている，KAWASUMI (1951) は歴史地震資料と震度の距離減衰式加定期間に経験 するであろう地震動強さ（震度と対応させた最大加速 度）の期待值を分布図として表現した（河角マップ）. 河 角マップは 1950 年に制定された建築基準法の地域係数 に取り入れられ，国あるいは地域の単位で地震危険度を 推定する，いわゆるマクロゾーネイションのさきがけで ある. 建築基準法の地域係数の策定にあたって, 当時の 議論が金井 (1967)によって紹介されている.

地震動予測に計測と理論的背景を付与したのが金井清 を中心とした日立鉱山における地下 150〜 450 m での 地震観測と基盤における地震動スペクトルの研究，表首 地盤での重複反射理論に関する研究, 地盤評価法として の微動観測などである [金井(1969)に集約されており, 個々の文献は省略する]. 気象庁で採用されたマグニ チュード決定式 [坪井 (1954)］と地下の地震観測記録之 を結び付けたいわゆる「金井式」は，地震動予測式とし て広く耐震工学の分野で用いられてきた。なお，「金井 式」は地盤を考慮した式, 震源近傍への適用と改良が加 えられてきたが，文献も含めて田中 (1985) による解説 が詳しい.

上にあげた「強震計の開発」「河角マップ」「金井式」 がその後の地震工学研究の礎であり, 発展の目標, 時に は批判の対象となってきた。

地盤（表首地質）が地震被害・地震動に及ぼす影響の 重要性に関してはわが国では古くから指摘されてきた。 定量評価のためには地震探査技術と測定結果が重要であ ることは，現在では極めて常識的な事柄である．地震探 查を地盤の評価に利用するさきがけ的研究は京都大学理 学部 [例えば, 吉川 (1949)] や地震研究所地盤研究会 (1955)によって行われている. 1953 年に結成された地 震探鉱実験グループの成果は後に地震工学に多大な貢献 をするが，当初はやや縁遠く，P波による構造探査（屈 折・反射法), 表面波の生成伝播の研究が中心であった. なお，同グループの結成，活動の経緯については，地震 探査研究の前史を含め, 田治米 (1976) が興味深い. 地表 付近の S 波速度を実測できるようになったのは，上記グ ループの実験で実施され, 多くの試行の結果生まれた 「板吒き法」[小林 (1959)] であり，1960 年代に入ってか ら地震工学分野で実用化されるようになった [例えば, 河角・他 (1966)]。 加えて, 孔中地震計の開発 [狐崎 (1967)］が S 波速度測定のルーチン化と, 測定深度を拡 大する役割を演じた。

1950 年代の国外に関連して特筆すべきことは，1956 年に第 1 回の世界地震工学会議が開催されたことであ る. また，この頃に地震応答スペクトルの考え方が導入 
されている [例えば, HoUSNER et al. (1953), HudSON (1956)].

\subsection{0 年代}

1960 年代に入り, SMAC 型・DC 型強震計が全国に 配備されるようになり，1967 年頃までには全国に 400 台強が設置されている [大沢・田中 (1967)]. 1962 年広 尾沖地震, 1964 年新潟地震, 1965 年から始まった松代 群発地震, 1968 年十勝沖地震などで観測された強震記 録は地震工学研究にとって極めて話題性に富んでいた. 広尾沖地震の際に, 釧路では当時の加速度記録としては 最大級の約 $0.4 \mathrm{~g}$ が観測されたが, 大加速度にも拘らず 構造物被害が皆無に近かった. そのため各種調查, 観測, 解析がおこなわれたが, 強震記録と（無）被害との関係 には必ずしも明確な解釈は得られていない［金井・酒井 (1970)]. この問題は 1993 年釧路沖地震において再びク ローズアップされ, 理解の進展が期待されているところ である. 新潟地震では, わが国初の震源近傍での強震記 録が得られ，また広域にわたる地盤の液状化が発生し， 土質力学と構造物基礎に関する研究を促したと言えよ j. 当時, 観測地点付近が液状化し, 液状化の記録への 影響が大きいと判断され, 震源近傍の地震動として地震 学的見地からの検討はなされなかった．新潟地震の影響 がまだ強く残っているさなか, 長野県松代町付近を震源 とする群発地震が発生し, 最大級の加速度 $0.6 \mathrm{~g}$ 強が得 られた [大沢・他(1976)]. 松代での震度は 5 であった が, 新潟地震で同じく震度 5 であった新潟市川岸町の記 録は高々 $0.16 \mathrm{~g}$ 程度であり, 加速度の差と震度・被害の 差について疑問が呈せられた. 1968 年十勝冲地震では 鉄筋コンクリート造の被害が発生し, 建築基準法施工令 の改定にもつながった，また，八戸港湾で観測された強 震記録には周期 2.5 秒の大加速度が含まれ, その現象理 解のために開始された, 都市域での中規模の人工地震探 查, 周期 1 秒を越える (やや長周期) 微動観測, 堆積層 表面波の検討等 1970 年代の研究テーマを提供した.

1950 年代後半から 1960 年代前半にかけて, 地震時 における地盤の振動性状に関する観測および解析的研究 が勢力的に行われている. それらは地中地震計の開発や $\mathrm{S}$ 波速度の実測が飛躍的に進展したことに負うところが 大である。これらについては嶋 (1967), 太田(1967)の 総合報告に詳しい.

1960 年代は地盤で卓越する地震動が $\mathrm{S}$ 波の重複反射 で説明できることの確認を行った時期とも言える. 当時 対象とされたのは中低層の構造物であり, 考虑する地震 動の周期もほぼ 1 秒以下, 地盤の厚さも $100 \mathrm{~m}$ 程度以 下に限定されていた．地震波が地款を伝播し地盤に入射 するという基本的考え方に立ち, 地款の $\mathrm{S}$ 波速度と地盤
のそれには 10 倍あるいはそれ以上の速度比があること を考慮すれば，地盤にはほぼ真下から地震波が入射する と近似し，その応答を 1 次元波動論で説明することは極 めて受け入れ易い考え方である. 現在でもその考え方の 実務的価值は高い。 ある地点の地震動評価から地域の地 震動評価に発展させるために導入されたのが「地震基 盤」の概念であり, 太田・嶋 (1967) による定義（地震基 盤 $1, \mathrm{~S}$ 波速度 $700 \mathrm{~m} / \mathrm{s}$ 程度）が試みられている. しか し，1970 年代に「やや長周期」（1～10 数秒）の地震動 がクローズアップされ基盤面はより深い地款の上面（地 震基盤 $2, \mathrm{~S}$ 波速度 $3 \mathrm{~km} / \mathrm{s}$ 程度）にすべきであるという 提案に変わっている. 入倉 (1983) が指摘するように, 地 震基盤の概念は地盤での地震動評価の実務的必要性から 生まれたものである. 現在, 急速な進展をみている $2 \cdot 3$ 次元の地下構造を考慮した地震動評価や強震記録の蓄積 に伴って, 地震動評価（予測）は必ずしも地震基盤の概 念を必要としない方向に進む可能性もある.

また，この時期に地盤での地震動特性推定のため, 金 井 清・田中貞二と共同研究者が勢力的に日本各地およ びカリフォルニア州等で微動の観測を進め, 建築基準 法・他の耐震基準に規定されている地盤種別のための評 価への微動の利用を提案している [金井 (1969)]。微動 特性の物理的意味付けをめぐっては, 1950 年代から 1960 年代にかけて，微動の波動的性質，つまり実体波 か表面波かの解釈, 微動源を中心に論争がくりひろげら れた [嶋 (1967), 野越 (1976) 等を参照].

1962 年に第 1 回の日本地震工学シンポジゥムが開催 され, 以後 4 年毎に地震学, 建築工学, 土木工学, 土質 工学, 機械工学の関係者の共通の議論の場になってい る.

\subsection{0 年代}

この時期を大きく特徴づけているのは,「断層モデル」 が地震工学に取り入れられ, 以前では地震学と工学の接 点が地盤での地震動であったのに対し, 震源を含めて共 通の対象となった。 また, 重要構造物（超高層ビル, 原 子力発電所, 長大橋など）の出現あるいは計画に伴って それぞれの構造物に対する入力地震動の研究が進んだこ と等をあげることができる.これに伴い，対象とする地 震動周期が 10 秒あるいはそれ以上に拡大し，考慮すべ き地盤の深さが時には数 $\mathrm{km}$ にも及ぶようになった。

「断層モデル」の理論的根拠が与えられたのは 1960 年代半ばにさかのぼるが, 理論地震記象を求め, 断層近 傍の観測記録を再現したAKI (1968) に, Strong Motion Seismology あるいは「断層モデル」を取り入れ た地震工学のルーツがあると言えよう. AKI (1968) が用 いた 1966 年 Parkfield 地震の強震記録はその後半無限 
媒質, 水平多層構造の理論記象への発展を促し, 1971 年 San Fernando 地震, 1979 年 Imperial Valley 地震 等の強震記録の解析を通じて震源近傍の地震動理解は急 速に進展した[岩田(1991)].「断層モデル」が直接地震 工学の分野で応用されるようになったのは1970 年代後 半であるが, 先駆的にはIRIKURA et al. (1970), 笹谷・鈴 木 (1975), 石田・大沢 (1975) 等の研究がある. 地震工 学の分野に強いインパクトを与えたのが太田・鏡味 (1976) であり,「断層モデル」を出発点とし, 折からニー ズの高まっていた「やや長周期」帯域の地震動評価に見 通しを与えた。

先に触れたように, 1968 年十勝沖地震で 2.5 秒ある いはそれを越える長周期の強震動が八戸で観測された。 八戸市で行われた中規模の地震探査 [岡田 (1971)] から 求められた深さ数百 $\mathrm{m}$ の基盤層 $(\mathrm{P}$ 波速度 $=5 \mathrm{~km} / \mathrm{s})$ と 地表構造がやや長周期の地震動の励起に深く関係するこ とが理解された.また, やや長周期の地震動に関連した微 動の観測研究 [例えば, 坂尻・他 (1974) 等] の発端とも なっている.

本格的に都市域での基盤構造探査が始められたのは 1975 年で, 震源の爆破点は東京都夢の島におかれた [嶋・他(1976)]。この調查は約 10 年ほど続けられ, 東 京都だけでなく, 神奈川県 [例えば, 瀬尾・小林 (1980)], 千葉県, 埼玉県, 茨城県の一部をふくむ首都圈 の基盤構造の詳細調查へと発展し，3 次元的基盤面の導 出に至っている [KoKETSU and HigASHI (1992)]. 1980 年代の初めに濃尾平野, 大阪平野, 静岡県南部などで屈 折法を中心とした中規模の地震探査が行われている. 1970 年代の初頭から, 地震予知研究計画の一環として 実施された首都圈での深層ボーリングと地震観測施設を 利用した速度検層がおこなわれ [太田・他(1977)], 基 盤層を含む上部の地盤構造が一層確かなものとなった。

1970 年代初頭に, わが国で発生した大地震の震源過 程（断層モデルの各種パラメターの決定）の研究が盛ん に行われた。 その中で, 例えば KANAMORI (1973), ABE (1974) は, 低倍率の変位計記録のシミュレーションを通 じて断層パラメターを決定している. そのシミュレー ション結果は地震工学にも強い影響を与えたが, $\mathrm{P} ・ \mathrm{~S}$ 波直達波のシミュレーションが主で周期も 10 数秒程度 以上が議論の対象とされ, 変位記録上に見られる周期数 秒の短周期の波は対象とされていなかった. 1974 年伊 豆半島沖地震による東京の変位記録に周期 6〜8 秒の継 続時間の長い地震動が観測された。このやや長周期の地 震動は, 東京の堆積層厚や弾性定数が推定されるように なったことを背景に, 堆積層表面波として説明すること ができ, 震源・伝播経路を考慮したシミュレーションが
可能となった [例えば, $\operatorname{KUDO}(1978,1980)]$ 。この周期 数秒から 10 数秒の強震動理解のために, 昔の低倍率の 記録 [田中・他 (1979)] や気象庁 1 倍強震計記録の解析 [例えば井上 (1986) を参照] も精力的に行われ, やや長 周期の地震動に関する知見が蓄積された。

先に述べたように，1960 年代以降にはわが国でも強 震記録を利用できるようになった. 米国では 1971 年 San Fernando 地震で 241 筒所におよぶ有効な強震記 録が得られ [JENNINGS and HOUSNER (1974)], それ以来 データが豊富になり，1970 年代, 1980 年代を通じて地 震動の最大加速度, 最大速度などの予測式 (距離減衰式) が数多く提案されてきた [CAMPBELL (1985), 服部 (1980), 田中・福島 (1987) などを参照]. 一方, 最大値 ではなく強震記録を基にスペクトルで表現された例も多 いが，この種の研究も主として 1970 年代に入ってから である. その代表例といえるのが小林・長橋 (1976), 翠 川・小林 (1978), 渡部・藤堂 (1982) や深井戸の地震記 録を用いた KINOSHITA (1984) 等で, 基盤での地震動ス ペクトルの距離減衰式を統計的に求めている.

1970 年代で更に特筆すべきことは, 1978 年に中・長 期的地震予知に基づいて東海（駿河湾）地震の発生を念 頭においた大規模地震対策特別措置法が制定されたこと である. 地震防災対策強化地域指定の基礎となったのが 技川・小林 (1979) であり, 地震予知との関連で特定の 地震を対象とした地震動予测が行われた始めての例であ ろう. 特定の地震のモデルが予測されるようになったこ とは, 当時プレートテクトニクス理論が地震学会を席巻 したことと深く関係している.

1968 年十勝沖地震の経験から建築基準法施工令が改 正された (1980 年) が, 以前河角マップに準拠していた 地域係数は, 地震動期待値に極值統計論を導入した尾 崎・他 (1978) を参考としたものに変更された。しかし， 地震活動度の評価として地震資料を用いており河角マッ プと基本的考え方は等しい. 歴史地震資料だけでは地震 活動度を十分に評価できないとの判断から, 活断層の分 布とそれぞれの断層の活動度を考慮した地震危険度評価 という新しい試みも行われている [WESNOUSKy et al. (1984)].

この種のマクロゾーネイションは, 定義は必ずしも明 確ではないが, 地震基盤への地震動を国あるいは地方の 単位で評価している. 一方, 都市あるいは地域という単 位で地震による影響を評価するマイクロゾーネイション の必要性が時代と共に高まってきた，地震防災対策に資 するための検討が始まったのは1960 年代の東京都, 川 崎市などの例をあげることができよう。 マイクロゾーネ イションにおいて最も基礎となる地震動予測は, 地盤で 
の增幅効果の評価につながるが, 評価を必要とする地域 に資料が整っているとは限らない. また, 計器観測によ る評価には限界があり, アンケートによる震度の高密度 調查が着目され [例えば太田・他(1979)], 1980 年代に かけて地震時人間行動, 避難の問題などに発展している.

1972 年に第 1 回の国際マイクロゾーネィション会議 が開催され, 地震学, 耐震工学だけでなく, 社会学, 政 治・経済を含む広い範囲の「地震の影響・対策」への研 究活動か開始されている. その後の発展を含めて鏡味 (1993) が詳しい.

国レベルでの重要構造物の耐震安全基準の策定にあ たって, 1960 年代から 1970 年代に広い範井で地震動 入力の検討が行われているが，その代表例として原子力 発電所の耐震安全性への考え方を表 (1990) が紹介して いる.

\subsection{0 年以降}

1978 年に国際地震工学会 (International Association for Earthquake Engineering) が組織して開催され た強震アレイ観測に関するワークショップ [IwAN (1978)] は次代の強震観測のあり方を提言するものと なった。この提言と時期を同じくしてディジタル強震計 が市販されるようになり, 特にわが国では速度型強震計 [村松 (1977)］ の普及むあって，第二世代の強震観测へ の移行のきっかけを作った. わが国では 1980 年代に 入ってすぐ駿河湾・伊豆半島, 関東平野, 仙台などで強 震アレイ観測が実現され，その後も足柄平野などに新設 されている. ある程度観測すべき地震を特定し，かつ密 度を高くし，面的に地震動をとらえ，質の高い記録を得 るという方向性が打ち出されている. 国外の例ではある が, Imperial Valley 地震, Michoacan 地震, Whittier Narrows 地震, Loma Prieta 地震で得られた強震記録 は, 不均質な断層運動の理解のための最も重要な資料と なっている. 限られた例ではあるが, 震源インバージョ ンから求めたモデルを用いて周期 1 秒以下の波形シ ミュレーションを可能にしている [例えば, HARTZELL and IIDA (1990), OURA et al. (1992) 等]. 気象庁はこれ までの 1 倍強震計から加速度センサーを用いた 87 型強 震計に順次変更した. また従来からの伝統のもとに進め られた強震観測も信号遅延, 絶対時刻の付加が伴うよう になり, ともすれば気象庁の強震データは地震学的利 用, 他の強震観測は工学的利用という 1970 年以前の図 式は，消えつつあると言えよう.

1970 年代から 1980 年前半に多くの興味を引いた運 動学的断層モデルを用いた決定論的地震動予測は, 二つ の弱点が指摘された. 弱点の第一は短周期（場合によっ て異なるがおおむね周期 1 秒以下）の地震動を評価（再
現）できないこと，第二はやや遠方での強震動の後続位 相を平行層近似では説明できないことである.

第一の問題点については，基本的に HASKELL (1969) モデルを用いているから短周期の変位スペクトル形状は $\omega^{-3}$ になり，観測から指摘されている「大局的には加速

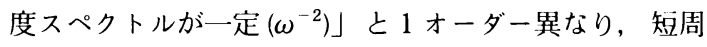
期を説明できないことは当然の帰結とも言える. そのた め, 震源 (断層運動) への不規則性の導入が様々な観点 から行われており [菊地 (1991)，入倉 (1992)などの総 合報告を参照], AKI (1967) にさかのぼることができる 統計的震源モデルの重要性があらためてクローズアップ された. $\omega^{-2}$ モデルでは加速度震源スペクトルは高周波 数域で平坦になるが, このスペクトル特性の高周波数限 界, いわゆる $f_{\text {max }}$ の存在についても多くの議論を呼ん た [例えば木下 (1988)]. 強震記録の統計解析から求め られていた地震動の経験式（距離减衰式）に物理的根拠 を与えようとする研究 [BoORE (1983), 武村・他 (1987) など]を通じて, 高周波の震源特性や地震波の減衰 $(Q)$ の究明に期待が持たれる.

第二の問題点は $2 \cdot 3$ 次元的不均質媒質の地震動への 考慮へと発展した. 1985 年 Michoacan 地震によるメキ シコ市の強震記録と建物の地震被害により，地盤震動の 問題があらためて国際的注目を喚起し, 盆地構造に代表 される $2 \cdot 3$ 次元地下構造を考慮した地震動予測・数值 シミュレーションの開発を促した.この边の事情は工 藤・東 (1989) および第 18 回地盤震動シンポジゥム $[\mathrm{H}$ 本建築学会 (1990)] 梗概集, 川瀬 (1993) に詳しい. 2 ・ 3 次元あるいは不整形地盤における波動伝播は決して新 しい問題ではないが [例えば，多賀 (1983) を参照]，そ の重要性が 1980 年代にあらためてクローズアップされ たと言えよう.

地震動予测手法として 1980 年代を席巻した一つが小 地震をグリーン関数とする方法 [例えば. IRIKURA (1983)］である. 地盤の不整形性を取り入れた複雑な数 值計算をすることなく, 小地震の加算によって長周期か ら短周期まで観测記録を良く再現することが示された。 また，地震動予測という工学的ニーズの他に，震源過程 を調べる上であ有力な方法である．しかし，入倉(1992) によって, 合成方法の課題として大地震の予測によ゙こま で小さい地震記録を使えるか, 多重震源の場合や小地震 記録のない場合にはよ゙うするかなどが指摘されている.

表層地質（地盤, 地形など）が地震動に及ぼす影響に 関しては，これまで見てきたように，1950年代（あるい はそれ以前）からわが国の地震工学の主要なテーマとし て検討が積み重ねられ, 進展の足跡も確固としたものが ある.しかし，国際的には必ずしも市民権を得た分野と 
は言えなかった，1970年代に入ってからは，むしろ諸 外国で, 複雑な地表・地下構造における波動の数値計算 法の開発や系統的な地震観測が行われるようになった。 1980 年代の後半から準備が進められ, 1990 年代に入っ てから実施に移された地震動予測に関する国際規模の実 験がある. その目的は地震動予測の定量化に向けて, 共 通のデータを用いた予測結果の比較を通じて各予測手法 の長・短所，限界性などを探ろうとするものである。テ ストフィールドとなった足柄平野は東京大学地震研究所 の強震観測網が展開されており (KuDo et al., 1988), そ こで得られた観測記録がもちいられた。予測の対象とな る地点の観測記録は予測結果が出そろうまで公表されな い，いわゆるブラインドプレディクションの方法が採用 された。詳細は IASPEI/IAEE JOINT WORKING GROUP (1992), 竹内 (1993) に謞るが, 足柄平野の実験では, 通 常, 地震動評価のために実施する地盤調查のレベルを越 える資料が用意されたものの，予測者が必要とする資料 （背景的資料む含む）のレベルにひらきがあった，そのた め多くの予測者は 1 次元波動論に基づく手法を採用し たが, 予測結果の平均値は, 観測をほぼ再現するものと なっている. 研究上の興味と実務の間に大きな差を実感 させる機会であった。

微動の観測とその利用は 1950 年代から続けられてき た。短周期の微動を地震動予測に直接利用できるかにつ いては一定の評価［例えば，瀬尾 (1989)］とともに悲観 的見方 [AKI (1988)] があることも事実である。それは単 に震動のレベルの問題ではなく, 微動源と微動の波動之 しての性質が明確でない，場所によって異なることが共 通の認識には至らせない困難性があると考えられる。 や や長周期の微動のアレイ観測は 1970 年代に試験的に開 始され，1980 年代には地下構造の推定を可能にした [HORIKE (1985), 岡田・他 (1990)]. 地下構造探査として の微動の新しい利用法であり, 人工地震探查では主とし て $\mathrm{P}$ 波速度構造が知られるが, 上記の結果は $\mathrm{S}$ 波速度 の情報を与え地震工学研究に大きく寄与するものと期待 される.

強震動時の地盤の非線形挙動の有無とその性質は極め て重要な事項であるが，本シリーズで翠川 (1993)によ り紹介されので割愛した.

\section{§3.おわりに}

Engineering Seismology の強震動観測・予測の問題 を中心にわが国の約 40 年間の研究の歩を駆け足で概観 してみた．地震学と耐震工学の接点となっている地盤震 動研究に重点が置かれ, Engineering Seismology 全体 をバランス良く触れることはできなかったきらいがある
がお許し戴きたい。

河角マップ・金井式に代表される $1950 ・ 1960$ 年代 の地震工学は結果の導出の過程にやや複雑さや, 定義の 不明確な点があるものの, 基本的には複雑な枝葉を取 り，見通しの良い表現が指向されている．経験の蓄積と 研究者が増加したことにより, 対象範囲の拡大, 予測精 度の向上を目指すが故の必然的な複雑化へと進んで来た ように見える．現象理解を目的とする場合は，どんな複 雑さをも厭わずに進めなければならないことは当然のこ とながら, 地震工学の分野では, 工学・地震防災への応 用を念頭に置かなければならない，本総合報告のシリー ズで, 現象理解の進展と応用への見通しが与えられるこ とを確信している．1970・1980 年代の強震動評価は, 地震学・地震工学者がかつての地盤震動問題を相互乗り 入れしていたことから震源にまでその領域が広がってい るが，これは地震学の断層モデルを中心とした確固たる 足跡の結果と言えるのではないだろうか.

なお参考文献は，これまでの総合報告「日本の地震学 の概観」,「地震動と地盤」 [日本建築学会 (1983)],

TAKEMURA et al. (1993) およびこれからシリーズで出さ れる各分野の総合報告で紹介されている（される）ので, 可能な限り省略した.

\section{謝辞}

本稿の Table の作成は太田 裕教授のお勧めによっ ており，また草稿の段階で地震工学の本質に関わる多く のご指摘を戴いた。 また，查読者の入倉孝次郎教授，笹 谷 努博士には想切なご指摘を戴いた。本シリーズは前 年度および今年度の地震編集委員会のご理解とご協力の 賜である．記して感謝申し上げる。

\section{参考文献}

AвE, K., 1974, Seismic displacement and ground motion near a fault: The Saitama earthquake of September 21, 1931, J. Geophys. Res., 79, 43934399.

АкІ, K., 1967, Scaling law of seismic spectrum, J. Geophys. Res., 72, 1217-1231.

Акг, K., 1968, Seismic displacement near a fault, J. Geophys. Res., 73, 5359-5376.

Акг, K., 1988, Local site effects on strong ground motion, Earthq. Eng. \& Soil Dynamics II-Recent Advances in Ground-Motion Evaluation, 103-155.

Boore, D. W., 1983, Stochastic simulation of high frequency ground motion based on seismological models of radiated spectra, Bull. Seism. Soc. Am., 73, 1865-1894.

Campbell, K. W., 1985, Strong motion attenuation relations: a ten-year perspective, Earthquake Spec- 
tra, 1, 759-804.

Haskell, N., 1969, Elastic displacements in the nearfield of a propagating fault, Bull. Seism. Soc. Am., 59, 865-908.

Hartzell, S. and M. IIDA, 1990, Source complexity of the 1987 Whitter Narrows, California, earthquake from the inversion of strong motion records, J. Geophys. Res., 95, 12475-12485.

服部定育，1980，世界地震活動域における地震危険度 MAP一地震活動度に基づいた最大加速度, 最大地動 速度の地域分布一，建築研究報告, 88, $99 \mathrm{pp}$.

Horike, M., 1985, Inversion of phase velocity of longperiod microtremors to the S-wave-velocity structure down to the basement in urbanized area. J. Phys. Earth, 33, 59-96.

Housner, G. W., R. P. Martel and J. L. Alford, 1953, Spectrum analysis of strong motion earthquakes, Bull. Seism. Soc. Am., 43, 97-119.

Hudson, D. E., 1956, Response spectrum techniques in engineering seismology, World Conf. Earthq. Eng. (Berkeley), 4 (1-12).

IASPEI/IAEE JOINT WorkING GROUP ON ESG, 1992, Proceedins of the Intern. Symp. on the Effects of Surface Geology on Seismic Motion, Vol. II-III, Assoc. for Earthq. Disas. Prev., 517 p.

井上凉介, 1986, やや長周期帯域における設計用入力地 震動研究の展望, 土木学会論文集, 374/I-6, 1-23.

入倉孝次郎, 1983 , 地震基盤, 地震動と地盤一地盤震動 シンポジゥム 10 年の歩み一, 日本建築学会, 93101.

入倉孝次郎, 1992, 震源のモデル化と強震動予测, 第 20 回記念地盤震動シンポジゥム (1992)（梗概集），日本 建築学会, 3-10.

IRIKURA, K., 1983, Semi-empirical estimation of strong ground motionds during large earthquake, Bull. Disas. Prev. Res. Inst., Kyoto Univ., 33, 63104.

Irikura, K., K. Matsuo and S. Yoshikawa, 1970, Vibrational characteristics of the ground near the epicenter-Analysis of strong motion accelerogram of Matsushiro earthquake, Proc. 3rd Japan Earthq. Eng. Symp. -1970, 285-292.

石田勝彦・大沢 饯, 1975, 震源特性を考慮した強震動 -1966 年 Parkfield 地震と 1968 年十勝沖地震一, 第 4 回日本地震工学シンポジゥム (1975) 講演集, 1522.

Iw AN, W. D. (Editor), 1978, Strong-motion earthquake instrument array, Proc. Intern. Workshop on Strong-Motion Earthquake Instrument Arrays, Hawaii, 103 p.

岩田知孝, 1991, 震源近傍の強震動とそれを用いた震源 過程の推定，地震 2 (特集号)，44, 315-327.

Jennings, P. C. and G. W. Housner, 1974, The San Fernando, California, earthquake of February 9, 1971, Proc. Fifth World Conf. Earthq. Eng., I, 1625.

地震研究所地盤研究会, 1955, 東京都地盤調查報告, 地
震研彙報, 33, 471-545.

鏡味洋史, 1993, サイスミックゾーネイション, 地震 2 , 46, 217-228.

金井 清, 1967, 耐震設計基準 (日本) と地震学, 日本 の地震学の概観, 地震 2, 20, 319-321.

金井 清, 1969 , 地震工学, 共立出版, $176 \mathrm{pp}$.

金井 清・酒井良男, 1970, 広尾沖地震における釧路の 強震記録と構造物の被害, 第 3 回日本地震工学シンポ ジゥム (1970) 講演集, 771-778.

KANAMORI, H., 1973, Mode of strain release associated with major earthquakes in Japan, Ann. Rev. Earth. Planet. Sci., 1, 213-239.

川瀬 博, 1993, 表層地質による地震波の増幅とシミュ レーション, 地震 $2,46,171-190$.

KAw ASUmi, H., 1951, Measures of earthquake danger and expectancy of maximum intensity throughout Japan as inferred from seismic activity in historical time, Bull. Earthq. Res. Inst., 21, 469-481.

河角 広・嶋 悦三・太田 裕・柳沢馬住・A. ARRAM, 宮川和志, 1966, 東京都内各所における S 波の測定結 果第 1 報, 地震研彙報, 44, 731-748.

菊地正幸, 1991, 震源過程の微細構造, 地震 2 (特集号), 44, 301-314.

Kinoshita, S., 1984, Spectral characteristics of bedrock motions in the Tokyo metropolitan area, Proc. of Japan Soc. Civil Eng., 344, 89-94.

木下繁夫, $1988, f_{\text {max }}$ 周辺の話題，地震 $2,41,629-629$.

狐崎長琅, 1967, 孔中固定式受震器による $\mathrm{S}$ 波の観測 (I), 物理探鉱, 20, 1-15.

小林直太, 1959, SH 波をつかって地下構造をきめる一 方法, 地震 $2,12,19-24$.

小林啓美・長橋純男, 1976, 地表で観測された地震動の 周期特性から求めた地盤の増幅特性之地震基盤におけ る地震動の性質, 日本建築学会論文報告集, 240, 7991.

Koketsu, K. and S. Higashi, 1992, Three-dimensional topography of the sediment/basement interface in the Tokyo Metropolitan Area, central Japan, Bull. Seism. Soc. Am., 82, 2328-2349.

Kudo, K., 1978, The contribution of Love waves to strong ground motions, Proc. 2nd Intern. Conf. Microzonation, San Francisco, 2, 765-776.

Kudo, K., 1980, The contribution of surface waves to strong ground motions, Proc. 7th World Conf. Earthq. Eng., 2, 499-506.

Kudo, K., E. Shima and M. Sakaue, 1988, Digital strong motion accelerograph array in Ashigara Valley-Seismological and engineering prospects of strong motion observation-, Proc. Ninth World Conf. Earthq. Eng., 8, 119-124.

工藤一嘉・東 貞成, 1989 , 強震動之 $2 \cdot 3$ 次元の地下 構造, 物理探查, 43, 430-442.

翠川三郎，1993，強震時にみられる地盤特性の非線形 性, 地震 2, 46, 207-216.

技川三郎・小林啓美, 1978 , 地震動の地震基盤加ら入 射スペクトルの性質, 日本建築学会論文報告集, 273 , 43-52. 
畆川三郎・小林啓美, 1979, 地震断層を考慮した地震動 スペクトルの推定, 日本建築学会論文報告集, 282 , 71-81.

村松郁栄, 1977, 速度型強震計の製作, 地震 $2,30,317-$ 338.

日本建築学会, 1983, 地震動と地盤一地盤震動シンポジ ウム 10 年の歩み一, 日本建築学会, $417 \mathrm{p}$.

日本建築学会, 1990 , 第 18 回地盤震動シンポジゥム： やや長周期地震動一現時点で予測はごこまで可能か 一, 日本建築学会, $90 \mathrm{p}$.

野越三雄, 1976 , 微動の研究経過, 地震波の生成・伝搬 に関する実験, 地震探鉱実験グループ, 119-131.

岡田 廣, 1971, 弾性波による八戸の基盤探査, 北海道 大学地球物理学研究報告, 26, 147-166.

岡田 廣・松島 健・森谷武男・笹谷 努, 1990, 広 域・深層地盤調查のための長周期微動探查法, 物理探 查, 43, 402-417.

表 俊一郎, 1990 , 原子炉施設の耐震設計用入力地震動 を定めるためには，どのように考えればよいであろう か, 物理探査, 43, 330-345.

大沢 胖・田中貞二, 1967, 自然地震の観測, 日本の地 震学の概観, 地震 2, 20, 290-293.

大沢 㭌・田中貞二・坂上 実・吉沢静代，1976, 松代 群発地震地域における強震記録のディジタル・デー

夕, 東京大学地震研究所強震計観測センター, $157 \mathrm{p}$.

太田 裕, 1967, 地表層の震動 (研究の現状), 日本の地 震学の概観, 地震 2, 20, 298-305.

太田 裕・嶋 悦三, 1967, 地震基盤について (1), 災害 科学論文集, 4, 133-135.

太田 裕・鏡味洋史, 1976 , 而震工学上考慮すべき地震 波の周期の上限と振幅の下限, 日本建築学会論文報告 集, 249, 53-60.

太田 裕・後藤典俊 - 塩野計司 - 高橋 博 - 山水史生 栗原重利, 1977, やや深い構造の S 波速度, 地震 2 , 30, 415-433.

太田 裕・後藤典俊・大橋ひとみ, 1979 , アンケートに よる地震時の震度の推定, 北海道大学工学部研究報 告, 92, 117-128.

Oura, A., S. Yoshida and K. Kudo, 1992, Rupture process of the Ito-Oki, Japan, earthquake of 1989 July 9 and interpretation as a trigger of volcanic eruption, Geophys. J. Int., 109, 241-248.

尾崎昌凡・北川良和・服部定育, 1978, 地震動の地域特 性に関する研究 (その 1), 日本建築学会論文報告集, 266, 31-40.

坂尻直巳 - 成瀬聖慈 - 竹内文朗 - 吉川賢一 - 後藤典俊 太田 裕, 1974, やや長周期の微動観測之地震_工学へ の適用 (1)一八戸市における予備観測一, 地震 2, 27, 338-351.

笹谷 努・鈴木貞臣, 1975，広尾沖地震 (1962) の震源 過程と長周期地震動, 第 4 回日本地震工学シンポジゥ
么 (1975) 講演集, 9-14.

瀬尾和大・小林啓美, 1980 , 人工地震による首都圈南西 部の地下深部探査一夢の島-江の島測線の地下構造一, 地震 2, 33, 23-36.

瀬尾和大, 1989, 微動観測とその工学的利用一メキシ コ・アメリカの事例から一, 第 17 回記念地盤震動シ ンポジゥム (1989) (梗概集), 日本建築学会, 83-90.

嶋 悦三, 1967, 地表層の震動 (研究の経過), 日本の地 震学の概観，地震 2, 20, 294-298.

嶋 悦三・柳沢馬住・工藤一嘉・吉井敏尅・一ノ瀬洋一 郎・瀬尾和大・山崎謙介・大保直人・山本喜俊・小口 雄康 - 長能正武, 1976, 東京の基盤構造, 地震研彙 報, 51, 1-11.

多賀直恒, 1983 , 不規則な構造の地盤震動, 地震動と地 盤一地盘震動シンポジゥム 10 年の歩み一, 日本建築 学会, 164-178.

田治米鏡二，1976，グループの生い立ち，地震波の生 成・伝搬に関する実験, 地震探鉱実験グループ, 1-2.

高橋竜太郎, 1953, SMAC 型強震計, 地震 2, 6, 117121.

武村雅之・太田外気晴 ・稗圃成人, 1987, 地震動の平均 スペクトルを評価する経験式の物理的基礎, 日本建築 学会構造系論文集, 375, 1-9.

Takemura, M., M. Motosaka and H. Yamanaka, 1993, Strong motion seismology in Japan, J. Phys. Earth, in press.

竹内吉弘 (編集), 1993, 地震動に与える表層地質の影 響に関する総合的研究, 平成 4 年度文部省科学研究費 補助金・総合研究 $(\mathrm{A})$ 研究成果報告書, $427 \mathrm{p}$.

田中貞二, 1985, 「金井式」に関する調查, ORI 研究報告 85-02, 大崎総合研究所, $37 \mathrm{p}$.

田中貞二・吉沢静代・大沢 胖, 1979, やや長周期帯域 における強震動の特性一長周期低倍率地震計記録の解 析一, 地震研彙報, 54, 629-655.

田中貞二・福島美光, 1987, 地震動強さの距離減衰, 第 15 回地盤震動シンポジゥム（梗概集），7-16.

坪井忠二, 1954, 地震動の最大振幅から地震の規模 $M$ を定めることについて，地震 2, 7, 185-193.

渡部 丹・藤堂正喜, 1982 , 設計用模擬地震動に関する 研究 その 2 模擬地震動の作成に必要な地震動特性 についての解析, 日本建築学会論文報告集, 312,6371.

Wesnousky, S. G., C. H. Scholz, K. Shimazaki and T. MAtsudA, 1984, Integration of geological and seismological data for the analysis of seismic hazard: A case study of Japan, Bull. Seism. Soc. Am., 74, 678708.

吉川宗治, 1949, 福井地震の震害之地盤, 防災研究所研 究報告第 2 号, 12-16. 